\title{
Increasing patch area, proximity of human settlement and larval food plants positively affect the occurrence and local population size of the habitat specialist butterfly Polyommatus coridon (Lepidoptera: Lycaenidae) in fragmented calcareous grasslands
}

\author{
ZuZanna M. ROSIN ${ }^{1}$, Piotr SKÓRKA ${ }^{2}$, Magdalena LENDA ${ }^{3}$, Dawid MOROŃ ${ }^{4}$, Tim H. SPARKS ${ }^{2}$ \\ and PIOTR TRYJANOWSKI ${ }^{2}$ \\ ${ }^{1}$ Department of Cell Biology, Faculty of Biology, Adam Mickiewicz University, Umultowska 89, 61-614 Poznań, Poland; \\ e-mail: zuziarosin@o2.p1 \\ ${ }^{2}$ Institute of Zoology, Poznań University of Life Sciences, Wojska Polskiego 71C, 60-625 Poznań, Poland \\ ${ }^{3}$ Institute of Environmental Sciences, Jagiellonian University, Gronostajowa 7, 30-387 Kraków, Poland \\ ${ }^{4}$ Institute of Systematics and Evolution of Animals, Polish Academy of Sciences, Sławkowska 17, 31-016, Kraków, Poland
}

Key words. Habitat fragmentation, Lepidoptera, Lycaenidae, Polyommatus coridon, metapopulation, patch occupancy

\begin{abstract}
Which factors influence the occurrence, population size and density of species in fragmented habitat patches are key questions in population and conservation ecology. Metapopulation theory predicts that larger and less isolated habitat patches should positively influence species occurrence and population size. However, recent studies have shown that habitat quality, human activity and permeability of the landscape surrounding habitat patches may be also important. In this paper we test the relative effects of habitat patch characteristics, human settlement and landscape permeability on the occurrence, local population size and density of the Chalk-hill Blue Polyommatus coridon a charismatic butterfly inhabiting calcareous grasslands in a fragmented landscape in southern Poland. Patch occupancy rate (corrected for the butterfly detection probability) was 0.45 . Habitat patch area, proximity of human settlement and cover of larval food plants positively affected occurrence of the Chalk-hill Blue. Local population size of the Chalk-hill Blue was positively affected by patch area and proximity of human settlement, and negatively by patch isolation. Local density was higher in patches located close to human settlement. Our study is one of the few showing a positive effect of human settlement on a grassland specialist butterfly although the mechanism hidden behind this phenomenon is unknown and requires further examination. In order to maintain local populations of the Chalk-hill Blue in southern Poland, conservation action should be focused on large, closely connected calcareous grasslands. Moreover, extensive management of this habitat should be maintained by local inhabitants who are better placed to undertake such work.
\end{abstract}

\section{INTRODUCTION}

Habitat fragmentation and a decrease of habitat quality may lead to local species extinctions and reduced recolonization rates (Thomas et al., 2001; Tscharntke \& Brandl, 2004). Local population dynamics in habitat fragments is the focus of metapopulation studies (Thomas et al., 1992; Hanski, 1994) which have been found applicable in many areas of nature conservation (Yuttham et al., 2003). As metapopulation theory (Levins, 1969) predicts, patch area and its isolation are the main factors driving species occurrence in habitat patches that are unevenly scattered in a landscape (e.g. Hill et al., 1996; Hokit et al., 1999). Patch size is often positively correlated with species population size (Hanski \& Ovaskainen, 2000; Hambäck \& Englund, 2005; Pellet et al., 2007). Small local populations inhabiting small patches are more vulnerable to extinction than large populations living in larger patches (Hanski, 1994; Hanski et al., 1995). Distance between patches is regarded as an index of patch isolation since the colonization probability of isolated patches is limited (Hanski, 1994; Hanski et al., 1995). Additionally, occupancy probability may be influenced by habitat quality.
Populations inhabiting high-quality patches show higher local densities, therefore they may be less susceptible to extinction than those of low-quality fragments (Dennis \& Eales, 1997; Thomas et al., 2001).

However, the effect of patch size, isolation and quality may interact with several further parameters such as human disturbance or permeability of the landscape matrix between patches (Murphy \& Lovett-Doust, 2004; Tscharntke \& Brandl, 2004). For example, in areas of high human density some areas may be trampled, littered or the behaviour of animals may be disturbed (Samejima et al., 2004; Stankowich \& Blumstein, 2005). Obviously, the permeability of the matrix as well as habitat patch characteristics are now inevitably the result of human activity (Dover \& Settele, 2009). Some elements in a landscape may be ecological corridors and others may be barriers that enhance and limit, respectively, the dispersal of individuals (Murphy \& Lovett-Doust, 2004; Grundel \& Pavlovic, 2007; Cozzi et al., 2008; Prevedello \& Vieira, 2009).

One of the habitat types that suffers from several human-related changes (e.g. abandonment of management, subsequent invasion of shrubs, high fragmentation 
due to agriculture intensification, habitat quality changes related to nutrient flow from surrounding farmland) is semi-natural calcareous grassland (Keymer \& Leach, 1990). In fact, in central Europe, many calcareous grasslands are limited to small isolated patches, often located on hills or limestone outcrops (Beneš et al., 2003; Krauss et al., 2004; Wenzel et al., 2006). This habitat, however, is of leading conservation interest because of a high richness of plant and insect species (Van Swaay, 2002; Walis DeVries et al., 2002). The insects are often important for crop production because many of them (bees, butterflies, hoverflies) may pollinate plants both in the calcareous grassland and in crops in surrounding farmland (Renwick \& Chew, 1994; Kevan, 1999). One of the most characteristic species occurring in fragmented calcareous grasslands is the Chalk-hill Blue Polyommatus coridon (Poda, 1761). This species may suffer from habitat fragmentation and human disturbance as it is sedentary with only a few individuals dispersing to other habitat patches (Schmitt et al., 2006). Earlier studies showed that local populations of this species had lower heterozigosity as population size decreased (Schmitt \& Seitz, 2002) and as distance to other Chalk-hill Blue populations increased (Krauss et al., 2004). Therefore, we considered it as a good model species for testing fragmentation related phenomena (Schmitt et al., 2006).

Based on metapopulation and landscape ecology concepts we predicted that Chalk-hill Blue should show higher probability of occupancy, larger local population sizes and higher density in patches that were: 1) larger, 2) less isolated, 3) of higher quality and 4) distant from human settlement. We also tested several variables describing matrix permeability/quality that may influence Chalk-hill Blue occurrence, local population size and density. They were: percentage cover of permanent grassland (possibly positively affecting dispersal among patches) and forest cover (possible barrier for dispersal).

\section{MATERIAL AND METHODS}

\section{Study area}

The study was conducted in 32 calcareous grassland patches in southern Poland $\left(50^{\circ} 01^{\prime} \mathrm{N} ; 19^{\circ} 54^{\prime} \mathrm{E}\right), 4-10 \mathrm{~km}$ southwest of Kraków city centre. The total area covered by calcareous grasslands was 87.3 ha and the study landscape covered ca. $40 \mathrm{~km}^{2}$. The calcareous grasslands (with the larval food plant which is Coronilla varia) were easily distinguishable from the surrounding landscape (dominated by arable land) as they were located on hills adjacent to the flat valley of the River Vistula. At the time of this study almost all habitat patches were unmanaged. Mowing was noted in two grassland patches: in one a small part ( $\sim 20 \%$ of the patch) was mown in late July 2008 and in the second grassland $70 \%$ of the patch was mown (two times: in June and August 2008). This second grassland patch was unoccupied by Chalk-hill Blue. We noted also one grassland patch where goats grazed grass and shrubs.

\section{Occupancy surveys and butterfly counts}

In all habitat patches we established 5 m-wide transects, on which the presence and number of individuals of the species was noted. The length of the transects were proportional to the patch area $(r=0.89, P<0.001)$, and varied between $30 \mathrm{~m}$ and $960 \mathrm{~m}$ (mean \pm SE: $248 \pm 46 \mathrm{~m})$. Counts were made between the $15^{\text {th }}$ July and $20^{\text {th }}$ August 2008. Three counts were made in each patch. The interval between counts was approximately one week. Butterflies were surveyed between 09:00 and 16:00 h during favourable weather conditions (maximum wind: 3 on the Beaufort scale, cloud cover up to $25 \%$, minimum temperature: $20^{\circ} \mathrm{C}$ ). The average speed of the transect walk was about $200 \mathrm{~m}$ per $10 \mathrm{~min}$. The minimum time spent counting butterflies was 5 min. This time was chosen because from our preliminary observations made in 2007 we knew the average time necessary to find the first butterfly during the transect walk was 2 min and 40 s (range: $40 \mathrm{~s}-4 \mathrm{~min}$ and $19 \mathrm{~s} ; N=11$ occupied patches). This time was independent of patch size $(r=0.207 ; P=0.542, N=$ 11). The order in which the potential habitat patches were checked was random.

\section{Environmental variables measured}

We measured the following environmental variables potentially affecting the occurrence, population size and density of Chalk-hill Blue in habitat patches:

1. Patch size (ha).

2. Distance to the nearest habitat patch (m); used as an index of patch isolation.

3. Distance to the nearest occupied habitat patch (m); used as an index of population isolation.

4. Distance to the nearest human settlement $(\mathrm{m})$ as a measure of human activity.

5. Percentage cover of permanent grassland within $500 \mathrm{~m}$ of the patch boundary. Grasslands may act as ecological corridors or stepping stones enhancing dispersal of the species.

6. Percentage cover of forest within $500 \mathrm{~m}$ of the patch boundary. Forest may act as a barrier to movement.

7. Abundance of flowering plants as nectar sources for adult butterflies. Depending on patch area 5-10 circular quadrats of 1 $\mathrm{m}$ diameter $\left(0.79 \mathrm{~m}^{2}\right)$ were randomly placed on each transect. Plant species richness, flower abundance and vegetation height were estimated within these quadrats in the middle of July (Skórka et al., 2007). We then summed the results across plant species within the quadrat and calculated the mean number of flowers/inflorescences per quadrat (Skórka et al., 2007).

8. Percentage cover of larval food plants in the habitat patch.

9. Wind protection $(\%)$. The percentage of the total length of the boundary of the habitat patch covered by forest or shrubs.

10. Mean height of vegetation $(\mathrm{cm})$, estimated from 10 random measurements of the herbaceous layer per quadrat (see 7 above) and averaged across quadrats (see: Skórka et al., 2007).

The environmental variables $1-6$ and 9 were calculated with the ImageJ software or directly in the field with the use of a GPS. Variables 7, 8 and 10 were measured during field surveys. We decided to measure landscape composition within a $500-\mathrm{m}$ radius from the patch boundary because Chalk-hill Blue covered only short distances both within habitat patches (mean \pm SE $22.4 \pm 1.9 \mathrm{~m}$, range: $1-83 \mathrm{~m}, N=21$ butterflies with 89 flight distances) and outside habitat patches (mean \pm SE $63.1 \pm 5.0 \mathrm{~m}$, range: $9-139, N=17$ butterflies with 49 flight distances; authors' unpubl. data). Therefore, this radius is probably the upper dispersal limit for most individuals of this species. The landscape composition within this distance probably encompasses most influences on butterfly local population dynamics. We also repeated our analysis with the landscape composition within a $1-\mathrm{km}$ radius around the habitat patches but this did not change our results (not shown). Autocorrelations among landscape predictors at nested radii are frequent and only the landscape scale showing the highest explanatory power should be used in multi-factor models (Steffan-Dewenter et al., 2002; Cozzi et al., 2008). 
TABLE 1. Basic characteristics of habitat patches occupied $(n=14)$ or unoccupied $(n=18)$ by Chalk-hill Blue in the study landscape.

\begin{tabular}{|c|c|c|c|c|c|c|c|c|}
\hline \multirow{2}{*}{ Variables } & \multicolumn{4}{|c|}{ Occupied } & \multicolumn{4}{|c|}{ Unoccupied } \\
\hline & Mean & $\mathrm{SE}$ & Min & Max & Mean & $\mathrm{SE}$ & Min & Max \\
\hline Patch size (ha) & 4.82 & 1.05 & 0.9 & 12.3 & 1.1 & 0.32 & 0.1 & 5.7 \\
\hline Distance to the nearest habitat patch (m) & 252 & 46.5 & 69 & 600 & 190 & 39.3 & 43 & 689 \\
\hline Distance to the nearest occupied habitat patch (m) & 490 & 191 & 69 & 1085 & 712 & 173 & 200 & 1654 \\
\hline Percentage cover of permanent grassland within $500 \mathrm{~m}$ & 18.4 & 3.93 & 3 & 43 & 26.1 & 3.89 & 2 & 54 \\
\hline Percentage cover of forest within $500 \mathrm{~m}$ & 30.3 & 7.11 & 0 & 80 & 26.3 & 3.96 & 5 & 67 \\
\hline Distance to the nearest human settlement (m) & 113 & 23.3 & 32 & 330 & 248 & 33.3 & 123 & 660 \\
\hline Abundance of flowering plants & 12.4 & 2.03 & 1 & 31 & 15 & 1.95 & 2 & 33 \\
\hline Percentage cover of larval food plant in the habitat patch & 11.2 & 1.04 & 5 & 17 & 6.0 & 0.74 & 1 & 12 \\
\hline Wind protection $\%$ & 45.7 & 6.87 & 12 & 78 & 35.8 & 4.62 & 16 & 76 \\
\hline Mean height of vegetation $(\mathrm{cm})$ & 22.3 & 3.31 & 2 & 43 & 24.2 & 3.77 & 6 & 57 \\
\hline
\end{tabular}

The basic characteristics of occupied and unoccopied patches are presented in Table 1.

\section{Estimation of occupancy probability}

We used an approach introduced by MacKenzie et al. (2002, 2005) and the patch occupancy was modelled using a generalized linear model with logit-link function. Presence-absence data and resulting estimates can be confounded by detection error, namely that a recorded "absence" may in fact be a nondetection of individuals rather than a true absence. Using such data with naive estimates will most likely result in underestimates of occupancy probability (MacKenzie et al., 2002, 2005). If a detection probability can be calculated, then unbiased estimators can be derived. The statistical procedures by MacKenzie et al. $(2002,2005)$ were deliberately proposed to include uncertainty in the detection probability of species. Calculation of detection probabilities requires that study sites (patches) were repeatedly surveyed (at least twice) in a given year/season. Calculations were performed with the program Presence 2.2 (Hines, 2006)

Akaike's Information Criterion corrected for small sample size (AICc) was used to identify the most parsimonious model from each candidate set. We ranked the models according to their $\Delta$ values and used the model with the lowest AICc value as that best describing the data. Where there was support for more than one model $(\Delta<2)$, we used the most inclusive model (the model that included the largest number of variables). We used model averaging for estimates of function slopes (betas) of parameters of interest (Cooch \& White, 1998). Due to small sample size we also examined standard errors and associated confidence intervals of the beta estimates and we report them as significant if the $95 \%$ confidence intervals do not overlap with zero. AICc values were also adjusted to allow for the extent of overdispersion measured by c-hat (Cooch \& White, 1998). An important consequence of adjusting c-hat is that sampling variances are inflated, which leads to a lower risk of falsely identifying a model factor as important, i.e., of making a Type 1 error (Lebreton et al., 2003). Recent literature increasingly advocates the use of AIC values as a standard model selection procedure (Burnham \& Anderson, 1998; Anderson \& Burnham, 1999). Using information criteria to select amongst candidate models obviates problems associated with multiple testing in classical statistics (Burnham \& Anderson, 1998). We standardized independent variables before the analysis to compare the relative influence of the variable estimates (betas).

TABLE 2. Correlation coefficients ( $P$-value in brackets) for investigated variables. Significant correlations $(P<0.05)$ are in bold. Sample size $n=32$ patches.

\begin{tabular}{|c|c|c|c|c|c|c|c|c|c|c|}
\hline & $(1)$ & $(2)$ & $(3)$ & $(4)$ & $(5)$ & $(6)$ & $(7)$ & $(8)$ & $(9)$ & $(10)$ \\
\hline (1) Patch area & - & $\begin{array}{c}0.312 \\
(0.082)\end{array}$ & $\begin{array}{l}-0.121 \\
(0.508)\end{array}$ & $\begin{array}{c}0.055 \\
(0.765)\end{array}$ & $\begin{array}{l}-0.007 \\
(0.971)\end{array}$ & $\begin{array}{l}-0.577 \\
(0.001)\end{array}$ & $\begin{array}{l}-0.195 \\
(0.285)\end{array}$ & $\begin{array}{c}0.169 \\
(0.355)\end{array}$ & $\begin{array}{c}0.153 \\
(0.402)\end{array}$ & $\begin{array}{l}-0.069 \\
(0.705)\end{array}$ \\
\hline (2) Distance to nearest habitat patch & & - & $\begin{array}{c}0.066 \\
(0.721)\end{array}$ & $\begin{array}{l}-0.169 \\
(0.354)\end{array}$ & $\begin{array}{l}-0.118 \\
(0.521)\end{array}$ & $\begin{array}{l}-0.066 \\
(0.718)\end{array}$ & $\begin{array}{l}-0.152 \\
(0.406)\end{array}$ & $\begin{array}{c}0.203 \\
(0.265)\end{array}$ & $\begin{array}{c}0.075 \\
(0.684)\end{array}$ & $\begin{array}{c}0.290 \\
(0.108)\end{array}$ \\
\hline $\begin{array}{l}\text { (3) Distance to nearest occupied habitat } \\
\text { patch (local population) }\end{array}$ & & & - & $\begin{array}{c}0.201 \\
(0.271)\end{array}$ & $\begin{array}{l}-0.119 \\
(0.516)\end{array}$ & $\begin{array}{c}0.050 \\
(0.786)\end{array}$ & $\begin{array}{c}0.113 \\
(0.538)\end{array}$ & $\begin{array}{l}-0.009 \\
(0.961)\end{array}$ & $\begin{array}{c}0.134 \\
(0.466)\end{array}$ & $\begin{array}{c}0.220 \\
(0.226)\end{array}$ \\
\hline (4) $\%$ cover of grassland within $500 \mathrm{~m}$ & & & & - & $\begin{array}{l}-0.445 \\
(0.011)\end{array}$ & $\begin{array}{l}0.013 \\
(0.945)\end{array}$ & $\begin{array}{c}0.053 \\
(0.775)\end{array}$ & $\begin{array}{l}0.036 \\
(0.843)\end{array}$ & $\begin{array}{l}-0.294 \\
(0.103)\end{array}$ & $\begin{array}{l}-0.066 \\
(0.719)\end{array}$ \\
\hline (5) $\%$ forest cover within $500 \mathrm{~m}$ & & & & & - & $\begin{array}{l}-0.109 \\
(0.554)\end{array}$ & $\begin{array}{c}0.049 \\
(0.791)\end{array}$ & $\begin{array}{l}-0.105 \\
(0.567)\end{array}$ & $\begin{array}{c}0.349 \\
(0.050)\end{array}$ & $\begin{array}{l}-0.254 \\
(0.161)\end{array}$ \\
\hline (6) Distance to human settlement & & & & & & - & $\begin{array}{l}-0.054 \\
(0.768)\end{array}$ & $\begin{array}{l}-0.184 \\
(0.313)\end{array}$ & $\begin{array}{l}-0.070 \\
(0.702)\end{array}$ & $\begin{array}{l}-0.075 \\
(0.685)\end{array}$ \\
\hline (7) Plant species richness & & & & & & & - & $\begin{array}{l}-0.140 \\
(0.445)\end{array}$ & $\begin{array}{l}-0.082 \\
(0.654)\end{array}$ & $\begin{array}{l}-0.001 \\
(0.995)\end{array}$ \\
\hline (8) Cover of larval food plant $\%$ & & & & & & & & - & $\begin{array}{l}-0.118 \\
(0.520)\end{array}$ & $\begin{array}{c}0.017 \\
(0.926)\end{array}$ \\
\hline (9) Wind protection $\%$ & & & & & & & & & - & $\begin{array}{c}0.036 \\
(0.843)\end{array}$ \\
\hline (10) Mean vegetation height $(\mathrm{cm})$ & & & & & & & & & & - \\
\hline
\end{tabular}


TABLE 3. Generalized linear models with logit-link function describing the effect of investigated variables on the Chalk-hill Blue presence/absence. The models ranked according to their $\triangle$ AICc Note abbreviations: "area" - patch area (ha); "build" - distance to the nearest human settlement (m); "larvalfood" - cover of larval food plants (\%); "vegetheight" - vegetation height; "habisol" - distance to the nearest habitat patch; "forest" - \% forest cover within $500 \mathrm{~m}$; "wind" - wind protection (\%); "popisol" - distance to the nearest occupied patch; "grassland" - \% cover of grassland within $500 \mathrm{~m}$; "plantrich" - flowering plant species richness; $\psi-$ probability of patch occupancy, $\mathrm{p}($.$) - detection probability of individuals independent on the survey; \mathrm{p}(\mathrm{t})$ survey-specific detection probability of individuals.

\begin{tabular}{|c|c|c|c|c|c|c|c|}
\hline No. & Model & $\mathrm{AICc}$ & $\Delta \mathrm{AICc}$ & $\begin{array}{c}\text { AIC } \\
\text { weight }\end{array}$ & $\begin{array}{c}\text { Model } \\
\text { likelihood }\end{array}$ & no.Par. & $-2 * \log \mathrm{L}$ \\
\hline 1 & $\psi($ area+build $), \mathrm{p}()$. & 37.81 & 0.00 & 0.45 & 1.00 & 4 & 68.33 \\
\hline 2 & $\psi($ area+build+larvalfood $), \mathrm{p}()$. & 38.76 & 0.95 & 0.28 & 0.62 & 5 & 64.94 \\
\hline 3 & $\psi($ area $), \mathrm{p}()$. & 40.81 & 3.00 & 0.10 & 0.22 & 3 & 76.41 \\
\hline 4 & $\psi($ area+build + vegetheight+larvalfood $), \mathrm{p}()$. & 42.07 & 4.26 & 0.05 & 0.12 & 6 & 66.71 \\
\hline 5 & $\psi($ area+habisol+build+vegetheight+larvalfood), p (.) & 42.31 & 4.50 & 0.05 & 0.11 & 7 & 63.64 \\
\hline 6 & $\psi(),. \mathrm{p}()$. & 42.44 & 4.63 & 0.04 & 0.10 & 2 & 78.03 \\
\hline 7 & $\psi($ area+habisol+forest+build+vegetheight+larvalfood $), \mathrm{p}()$. & 44.50 & 6.69 & 0.02 & 0.04 & 8 & 62.24 \\
\hline 8 & $\psi($ area + habisol+forest + build + vegetheight + larvalfood + wind $), p()$. & 47.37 & 9.56 & 0.00 & 0.01 & 9 & 61.19 \\
\hline 9 & $\begin{array}{l}\psi \text { area+popisol+habisol+forest }+ \text { build }+ \text { vegetheight }+ \text { larvalfood }+ \\
\text { wind), p (.) }\end{array}$ & 51.02 & 13.21 & 0.00 & 0.00 & 10 & 60.54 \\
\hline 10 & $\psi(),. \mathrm{p}(\mathrm{t})$ & 51.89 & 14.08 & 0.00 & 0.00 & 4 & 83.70 \\
\hline 11 & $\begin{array}{l}\psi(\text { area }+ \text { popisol }+ \text { habisol }+ \text { forest }+ \text { grassland }+ \text { build }+ \text { vegetheight }+ \\
\text { larvalfood }+ \text { wind }), \mathrm{p}(.)\end{array}$ & 62.63 & 24.82 & 0.00 & 0.00 & 11 & 62.21 \\
\hline 12 & $\begin{array}{l}\psi(\text { area }+ \text { popisol }+ \text { habisol }+ \text { forest }+ \text { grassland }+ \text { build }+ \text { vegetheight }+ \\
\text { larvalfood }+ \text { wind }+ \text { plantrich }), p(.)\end{array}$ & 65.91 & 28.11 & 0.00 & 0.00 & 12 & 65.49 \\
\hline
\end{tabular}

Parameter estimates are given with standard errors (SE) throughout the paper.

\section{Estimation of factors affecting local population size and den- sity}

Because only 14 patches were occupied by the species (see: results) we decided against a multiple regression model to test the joint effect of environmental variables on local population size and density. Instead, we used simple correlation analysis for each environmental factor. Population size was estimated as the sum of the individuals noted within the transects on the three survey counts. Small species from the Lyceanidae family, related to Chalk-hill Blue, live only a few days on average (e.g. Nowicki et al., 2005a), thus we think that summing the number of individuals across counts was reasonable. Local population density was calculated as the mean number of individuals per 1 ha per transect count. We also checked for correlation among the environmental variables to reveal possible relationships among explanatory variables (Table 2 )

\section{RESULTS}

From 32 potential habitat patches 14 were occupied by Chalk-hill Blue (occupancy corrected for detection probability was $0.45 \pm 0.19$ ). The model with constant detection probability had better support than the model with a survey-specific one (models 6 and 10 in Table 3). The detection probability of the species during the survey was $0.78 \pm 0.06$.

The best model describing patch occupancy of Chalkhill Blue contained patch area and distance to the nearest human settlement (model 1 in Table 3 ). A more complex model containing patch area, distance to human settlement as well as cover of larval food plants (model 2 in Table 3) was equally good. Within the model, the probability of patch occupancy was positively related to patch area (beta $=1.97 \pm 0.47$, Fig. 1a) and negatively to dis- tance to the nearest human settlement (patches close to human settlement were more likely to be occupied by $P$. coridon; beta $=-1.84 \pm 0.70$, Fig. 1b). Patch occupancy was also positively related to cover of larval food plants $(3.18 \pm 1.54$, Fig. 1c). Mean size of the local population was $12.1 \pm 2.76$ individuals (range: $2-34$ ). The local population size of the Chalk-hill Blue was positively correlated with patch area $(r=0.74, P=0.001$, Fig. 2a), negatively with distance to human settlement $(r=-0.66$, $P=0.010$, Fig. 2 b) and with patch isolation $(r=-0.52, P$ $=0.057$, Fig. $2 \mathrm{c}$ ), however, the latter relationship was only marginally significant. We also found that patch area was negatively correlated with distance to human settlement (Table 2). Therefore, we calculated partial correlation coefficients between population size, distance to human settlement and patch area to exclude the effect of the latter variable. The partial correlation between abundance and distance to human settlement was still significant (partial $r=-0.55, P=0.041$ ) after accounting for patch area.

Mean local density was $24.6 \pm 5.9$ individuals per hectare (range: 7.8-88.9). Density was negatively correlated with distance to nearest human settlement but only after accounting for patch area (partial $r=-0.59, P=0.026$ ). Other factors did not significantly affect local densities.

Other significant correlations among patch characteristics were found between percentage cover of forest and wind protection (positive), and between percentage cover of forest and percentage cover of grassland (negative) (Table 2).

\section{DISCUSSION}

The results showed the importance of habitat patch area in explaining the probability of Chalk-hill Blue occur- 

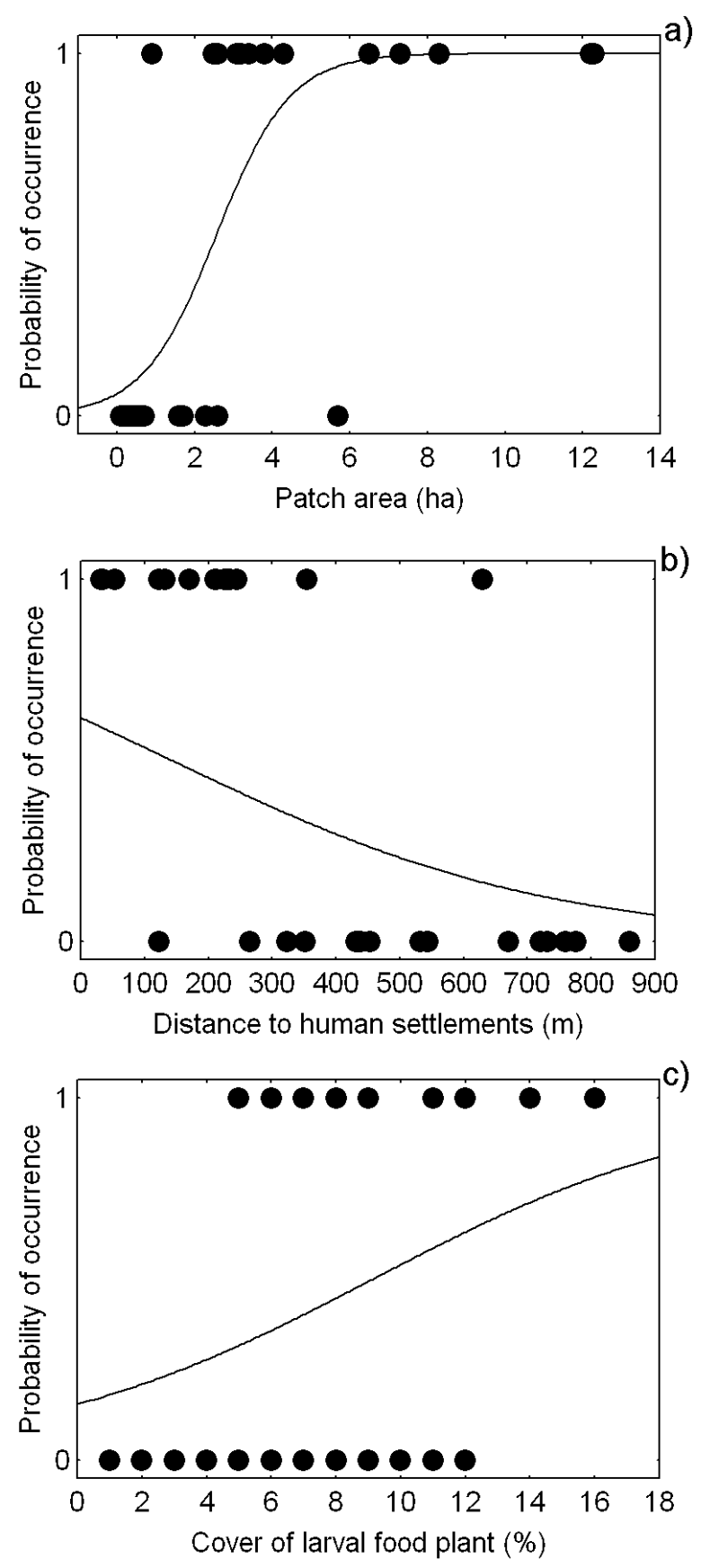

Fig. 1. Effects of (a) habitat patch area, (b) distance to human settlement and (c) cover of larval food plant on the probability of occurrence of Polyommatus coridon in calcareous grasslands (logistic curve fitted).

rence and local population size in this study landscape. Previous studies on Chalk-hill Blue (Krauss et al., 2005) and other butterflies (e.g. Hesperia comma, Hill et al., 1996; Melitaea cinxia, Hanski et al., 1995) also confirmed that patch size is a good predictor of patch occupancy and population size (Hanski, 1994; Hanski \& Ovaskainen, 2000). Population size and hence its resistance to environmental stochasticity increases with patch size (Hanski, 1994; Hanski et al., 1995) thus proper management of large habitat fragments might play a vital role in species conservation. It seems especially important in
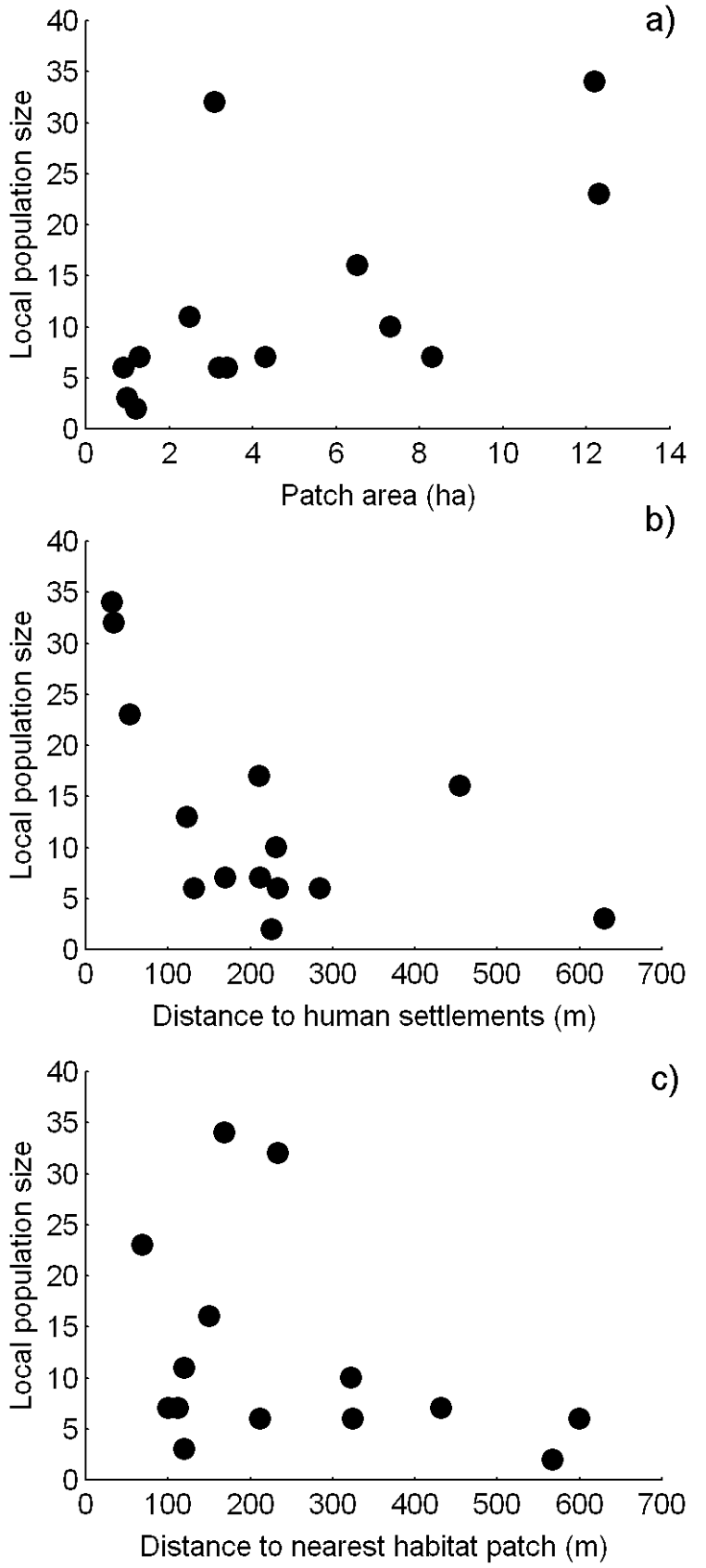

Fig. 2. Relationship between (a) patch area, (b) distance to human settlement, (c) distance to nearest habitat patch and local population size of Polyommatus coridon (sum of individuals noted during three surveys).

the case of Chalk-hill Blue since its population heterozigosity shows a reduction in small and highly isolated habitat fragments (Schmitt \& Seitz, 2002; Krauss et al., 2004).

However, patch isolation did not significantly contribute to the explanation of Chalk-hill Blue occurrence but was nearly significant as far as population size of this species was concerned. This variable had a nonsignificant effect on Chalk-hill Blue occurrence and density in a fragmented landscape of central Germany (Krauss et al., 2005). The effect of patch isolation is very marked in the case of species characterized by a low dispersal ability 
and large distances between conspecific habitat fragments (Murphy \& Lovett-Doust, 2004; Tscharntke \& Brandl, 2004). Chalk-hill Blue is considered a sedentary species (Cowley et al., 2001; Brereton et al., 2008). A study based on mark-release-recapture (MRR) conducted on Chalk-hill Blue inhabiting south-west Germany confirmed this statement (only $3.2 \%$ of the recaptured individuals moved between patches; Schmitt et al., 2006). Thus our results, and those of Krauss et al. (2005), contrast with expectations. This might be due to relatively low mean distances between the patches in our study landscape (and also those of Krauss et al., 2005) in comparison to the landscape studied by Schmitt et al. (2006). Therefore, the patch network in our study landscape was probably sufficiently compact to allow successful dispersal of Chalk-hill Blue and hence reduce the effect of patch isolation on the species' occurrence. This hypothesis should be treated with some caution. Sample size might have been insufficient to detect significant relationships between patch isolation and occupancy. Moreover, as expected, population size of the Chalk-hill Blue was marginally significantly (negatively) related to habitat isolation.

Chalk-hill Blue occurrence, population size and local density were negatively correlated with distance to the nearest human settlement. This is in contrast to our prediction that proximity of human settlement (as a measure of human activity) will adversely affect our study species. Indeed, distance to human settlement was positively correlated with patch area, but after controlling for the effect of the latter variable it still remained significant. This might be due to land management patterns in our study site. It is possible that grasslands located closer to settlements may have been cut more frequently or generally managed in a different way to those more distant. However, currently, most of the calcareous grasslands are unmanaged. Unfortunately, we do not have any historical data on management schemes in our study grasslands that could have been helpful in explaining the observed effect of the presence of human settlement on patch occupancy and population size. The grasslands close to farms could be those abandoned last and, therefore, probably the most favourable to Chalk-hill Blue since this species prefers agriculturally managed but unimproved calcareous grasslands (Brereton et al., 2008). It is also possible that people living in the neighbourhood and visiting the patches (most are located in a nice and scenic landscape) may prevent shrub succession to some degree due to trampling and therefore they may create microhabitats for the butterfly. Another possibility is that the study species may benefit from the proximity of human settlement because most of them are single-family houses often possessing flower-rich gardens. Thus, gardens might be a collateral source of nectar for this butterfly. It is noteworthy that the second larval food plant Hippocrepis comosa is sometimes planted in gardens but was never noted in our calcareous grasslands. We also noted that some inhabitants in the area possess goats and cows that occasionally feed in grasslands near the houses. This may also explain why the proximity of human settlement may be beneficial for the studied species since it was found that beef cattle and sheep numbers positively correlated with P. coridon abundance (Brereton et al., 2008). Moreover, an increase in stock grazing level in calcareous grasslands greatly contributed to the recovery of $P$. coridon populations (Brereton et al., 2005). This may be due to the important role of herbivores in maintaining landscape diversity which is favourable for this species (Brereton et al., 2008) and for dispersal of the larval food plants (Barbaro et al., 2001). The results from other studies are ambiguous, however. Some of them showed a significant negative effect of human activity on butterfly populations (Kitahara \& Fujii, 1994; Clark et al., 2007) while others did not find any effect (e.g. Collinge et al., 2003; Nowicki et al., 2007). Therefore, the effect of human settlement on this species requires more detailed examination.

Among investigated variables describing patch quality only larval food cover added significantly to the explanation of Chalk-hill Blue occurrence. The distribution of larval food plants has proved to be of high importance for many butterfly species (e.g. Nowicki et al., 2005b; Betzholtz et al., 2007; Bauerfeind et al., 2009, De Groot et al., 2009) including Chalk-hill Blue (Krauss et al., 2005; Brereton et al., 2008). Thus, the quality of a patch can, to some extent, act as a substitute for patch area (Hanski \& Ovaskainen, 2000) and enhance the predictive power of metapopulation models (Thomas, 2001). This has important practical implications apart from just providing larval food plants; thus managing them (e.g., via trampling or via scrub removal) for the butterfly may be fundamental.

\section{CONCLUSIONS}

Our results indicate that if we want to maintain local populations of Chalk-hill Blue in southern Poland then management and conservation actions should be focused on large, closely connected calcareous grasslands. Within these patches the maintenance of a substantial quantity of the larval food plant is probably also the key factor in Chalk-hill Blue conservation. However, it is difficult to extend our assumptions to other regions. This may mean that successful conservation of this species requires local knowledge of the key factors important for a target area rather than general recommendations. Our study is unusual in indicating that the presence of human settlement in the proximity of habitat patches may be beneficial for habitat specialists, i.e. the study species. This, however, requires further testing to identify the mechanism hidden behind the observed patterns of occurrence, local population size and density.

ACKNOWLEDGEMENTS. We thank M. Konvička, D. Hypšová and two anonymous referees for helpful comments on an earlier version of this manuscript.

\section{REFERRENCES}

Anderson D.R. \& Burnham K.P. 1999: General strategies for the analysis of ringing data. Bird Study 46: 261-270. 
Barbaro L., Dutoit T. \& Cozic P. 2001. A six-year experimental restoration of biodiversity by shrub clearing and grazing in calcareous grasslands of the French Prealps. Biodivers. Conserv. 10: 119-135.

Bauerfind S.S., Theisen A. \& Fisher K. 2009: Patch occupancy in the endangered butterfly Lycaena helle in a fragmented landscape: effects of habitat quality, patch size and isolation. J. Insect. Conserv. 13: 271-277.

Beneš J., KePKa P. \& KonvičKa M. 2003: Limestone quarries as refuges for European xerophilous butterflies. Conserv. Biol. 17: 1058-1069.

Betzholtz P.E., Ehrig A., Lindeborg M. \& Dinnetz P. 2007: Food plant density, patch isolation and vegetation height determine occurrence in a Swedish metapopulation of the marsh fritillary Euphydryas aurinia (Rottemburg, 1775) (Lepidoptera, Nymphalidae). J. Insect Conserv. 11: 343-350.

Brereton T.M., Wigglesworth T., Warren M.S. \& Stewart K. 2005: Agri-environment Schemes and Butterflies: Reassessing the Impacts of and Improving Delivery of Biodiversity Action Plan Targets. Butterfly Conservation Final Project Report, Defra.

Brereton T.M., Warren M.S., Roy D.B. \& Stewart K. 2008 : The changing status of the Chalkhill Blue butterfly Polyommatus coridon in the UK: the impacts of conservation policies and environmental factors. J. Insect Conserv. 12: 629-638.

Burnham K.P. \& Anderson D.R. 1998: Model Selection and Inference: A Practical Information-theoretic Approach. Springer, New York, 488 pp.

Clark P.J., ReEd J.M. \& ChEW F.S. 2007: Effects of urbanization on butterfly species richness, guild structure, and rarity. Urban Ecosyst. 10: 321-337.

Collinge S.K., Prudic K.L. \& Oliver J.C. 2003: Effects of local habitat characteristics and landscape context on grassland butterfly diversity. Conserv. Biol. 17: 178-187.

Cooch E.G. \& White G. 1998: Using MARK - a gentle introduction. http://www.phidot.org/software/mark/docs/book/

Cowley M.J.R., Thomas C.D., Roy D.B., Wilson R.J., LéonCortés J.L., Guitiérrez D., Bulman C.R., Quinn R.M., Moss D. \& GASton K.J. 2001: Density-distribution relationships in British butterflies. I. The effect of mobility and spatial scale. J. Anim. Ecol. 70: 410-425.

Cozzi G., Müller C.B. \& Krauss J. 2008: How do local habitat management and landscape structure at different spatial scales affect fritillary butterfly distribution on fragmented wetlands? Landsc. Ecol. 23: 269-283.

De Groot M., Rebeušek F., Grobelnik V., Govedič M., Šalamun A. \& Verovnik R. 2009: Distribution modeling as an approach to the conservation of a threatened alpine endemic butterfly (Lepidoptera: Satyridae). Eur. J. Entomol. 106: $77-84$.

DenNis R.L.H. \& Eales H.T. 1997: Patch occupancy in Coenonympha tullia (Müller, 1764) (Lepidoptera: Satyrinae): habitat quality matters as much as patch size and isolation. $J$. Insect Conserv. 1: 167-176.

Dover J. \& Settele J. 2009: The influences of landscape structure on butterfly distribution and movement: a review. $J$. Insect. Conserv. 13: 3-27.

Grundel R. \& PAVlovic N.B. 2007: Resource availability, matrix quality, microclimate, and spatial pattern as predictors of patch use by the Karner blue butterfly. Biol. Conserv. 135: $135-144$.

Hambäck P.A. \& Englund G. 2005: Patch area, population density and the scaling of migration rates: the resource concentration hypothesis revisited. Ecol. Letters 8: 1057-1065.

HANSKI I. 1994: A practical model of metapopulation dynamics. J. Anim. Ecol. 63: 151-162.
HANSKi I. \& OvasKainen O. 2000: The metapopulation capacity of a fragmented landscape. Nature 404: 755-758.

Hanski I., Pakkala T., Kuussaari M. \& Lei G. 1995: Metapopulation persistence of an endangered butterfly in a fragmented landscape. Oikos 72: 21-28.

HiLl J.K., Thomas C.D. \& Lewis O.T. 1996: Effects of habitat patch size and isolation on dispersal by Hesperia comma butterflies: implications for metapopulation structure. J. Anim. Ecol. 65: 725-735.

Hines J.E. 2006: Presence 2.2. Software to Estimate Patch Occupancy and Related Parameters. USGS-PWRC, Laurel, MD. http://www.mbrpwrc.usgs.gov/software/presence.html

Hoкit D.G., Stith B.M. \& Branch L.C. 1999: Effects of landscape structure in Florida scrub: a population perspective. Ecol. Appl. 9: 124-134.

Kevan P.G. 1999: Pollinators as bioindicators of the state of the environment: species, activity and diversity. Agr. Ecosyst. Environ. 74: 373-393.

Keymer K. \& Leach S.J. 1990: Calcareous grasslands - a limited resource in Britain. In Hillier S.H., Walton D.H.W. \& Wells D.A. (eds): Calcareous Grasslands: Ecology and Management. Bluntisham Books, Huntington, pp. 11-20.

Kitahara M. \& FuJI K. 1994: Biodiversity and community structure of temperate butterfly species within a gradient of human disturbance: an analysis based on the concept of generalist vs. specialist strategies. Res. Popul. Ecol. 36: 187-199.

Krauss J., Schmitt T., Seitz A., Steffan-Dewenter I. \& TscharntKe T. 2004: Effects of habitat fragmentation on the genetic structure of the monophagous butterfly Polyommatus coridon along its northern range margin. Mol. Ecol. 13: 311-320.

Krauss J., Steffan-Dewenter I., Müller C.B. \& TscharntKe T. 2005: Relative importance of resource quantity, isolation and habitat quality for landscape distribution of a monophagous butterfly. Ecography 28: 465-474.

Lebreton J.D., Hines J.E., Pradel R., Nichols J.D. \& SpenDELOW J.A. 2003: Estimation by capture-recapture of recruitment and dispersal over several sites. Oikos 101: 253-264.

MacKenzie D.I., Nichols J.D., Lachman G.B., Droege S., Royle A. \& Langtimm C.A. 2002: Estimating site occupancy rates when detection probabilities are less than one. Ecology 83: $2248-2255$.

MacKenzie D.I., Nichols J.D., Sutton N., Kawanishi K. \& BAILEY L.L. 2005: Improving inferences in population studies of rare species that are detected imperfectly. Ecology 86: 1101-1113.

Murphy H.T. \& LovetT-Doust J. 2004: Context and connectivity in plant metapopulations and landscape mosaics: does the matrix matter? Oikos 105: 3-14.

Nowicki P., Witek M., Skórka P., Settele J. \& Woyciechowski M. 2005a: Population ecology of the endangered butterflies Maculinea telejus and M. nausithous and the implication for conservation. Popul. Ecol. 47: 193-202.

Nowicki P., Witek M., Skórka P. \& Woyciechowski M. 2005b: Oviposition patterns in the myrmecophilous butterfly Maculinea alcon (Lepidoptera: Lycaenidae) in relation to characteristics of foodplants and presence of ant hosts. Pol. J. Ecol. 53: 409-417.

Nowicki P., Pęroowska A., KudŁek J., Skórka P., Witek M., Settele J. \& WoyciechowsKi M. 2007: From metapopulation theory to conservation recommendations: lessons from spatial occurrence and abundance patterns of Maculinea butterflies. Biol. Conserv. 140: 119-129.

Pellet J., Fleishman E., Dobkin D.S., Gander A. \& Murphy D.D. 2007: An empirical evaluation of the area and isolation 
paradigm of metapopulation dynamics. Biol. Conserv. 483-495.

Prevedello J.A. \& Vieira M.V. 2010: Does the type of matrix matter? A quantitative review of the evidence. Biodivers. Conserv. 19: 1205-1223.

Renwick J.A. \& Chew F.S. 1994: Oviposition behavior in Lepidoptera. Annu. Rev. Entomol. 39: 377-400.

Samejima H., Marzuki M., Nagamitsu T. \& Nakasizuka T. 2004: The effects of human disturbance on a stingless bee community in a tropical rainforest. Biol. Conserv. 120: $577-587$.

Schmitt T. \& Seitz A. 2002: Influence of habitat fragmentation on the genetic structure of Polyommatus coridon (Lepidoptera: Lycaenidae): implications for conservation. Biol. Conserv. 107: 291-297.

Schmitt T., Habel J.C., Besold J., Becker T., Johnen L., Knolle M., Rzepecki A., Schultze J. \& Zapp A. 2006: The Chalk-hill Blue Polyommatus coridon (Lycaenidae, Lepidoptera) in a highly fragmented landscape: How sedentary is a sedentary butterfly? J. Insect Conserv. 10: 311-316.

Skórka P., Settele J. \& Woyciechowski M. 2007: Effects of management cessation on grassland butterflies in southern Poland. Agr. Ecosyst. Environ. 121: 319-324.

Stankowich T. \& Blumstein D.T. 2005: Fear in animals: a meta-analysis and review of risk assessment. Proc. R. Soc. Lond. (Biol.) 272: 2627-2634.
Steffan-Dewenter I., Münzenberg U., Bürger C., Thies C. \& TscharntKe T. 2002: Scale dependent effects of landscape context of three pollinator guilds. Ecology 83: 1421-1432.

Thomas C.D., Thomas J.A. \& WarRen M.S. 1992: Distribution of occupied and vacant butterfly habitats in fragmented landscapes. Oecologia 92: 563-567.

Thomas J.A., Bourn N.A.D., Clarke R.T., Stewart K.E., Simcox D.J., Pearman G.S., Curtis R. \& Goodger B. 2001: The quality and isolation of habitat patches both determine where butterflies persist in fragmented landscapes. Proc. $R$. Soc. Lond. (B) 268: 1791-1796.

TSCharntKe T. \& BRandL R. 2004: Plant-insect interactions in fragmented landscapes. Annu. Rev. Entomol. 49: 405-430.

VAN SWAay C.A.M. 2002: The importance of calcareous grasslands for butterflies in Europe. Biol. Conserv. 104: 315-318.

Wallis De Vries M.F., Poschlod P. \& Willems J.H. 2002: Challenges for the conservation of calcareous grasslands in northwestern Europe: integrating the requirements of flora and fauna. Biol. Conserv. 104: 265-273.

Wenzel M., Schmitt T., Weitzel M. \& Seitz A. 2006: The severe decline of butterflies on western German calcareous grasslands during the last 30 years: A conservation problem. Biol. Conserv. 128: 542-552.

Yuttham K., Jaroensutasinee M. \& Jaroensutasinee K. 2003: Metapopulation and its application in conservation biology. $J$. Sci. Technol. 25: 395-409.

Received February 10, 2010; revised and accepted June 25, 2010 